\title{
JUSTICE DICKSON'S THIRTY-YEAR INFLUENCE ON INDIANA CONSTITUTIONAL LAW*
}

\author{
JON LARAMORE ${ }^{* *}$
}

\section{INTRODUCTION}

Indiana constitutional law evolved significantly over the thirty years Justice Brent E. Dickson served on the Indiana Supreme Court, and he is as responsible for that evolution as any other single person. Put another way, no other individual had more to do with the development of Indiana constitutional law since the $1980 \mathrm{~s}$ than Justice Dickson.

His influence can be seen across constitutional law-freedom of religion, freedom of speech, double jeopardy, search and seizure, equal privileges and immunities, the Special Laws Clauses, the Open Courts Clause, and many other aspects of Indiana constitutional law. ${ }^{1}$ His contributions have been in both majority opinions and dissents, some of which have later been adopted as the majority view. Other articles in this festschrift will address Justice Dickson's contributions to the law of freedom of religion as well as both constitutional and non-constitutional aspects of tort law and criminal law. This Article bats clean-up on the constitutional issues not addressed by the other authors, although it does not purport to cover every Dickson-influenced state constitutional decision.

\section{THE INTERPRETIVE STANDARD}

Over and above the individual decisions, Justice Dickson has had as much influence as anyone on the standard the Indiana Supreme Court has adopted over the last thirty years to determine the meaning of the Indiana Constitution, what this Article refers to as the "interpretive standard." Justice Dickson has attributed the interpretive standard to Chief Justice Randall T. Shepard, his long-time colleague, ${ }^{2}$ but Justice Dickson himself played an important role in developing

* Most elements of this Article were initially presented at the March 29, 2016 symposium at Indiana University Robert H. McKinney School of Law entitled A Tribute to Justice Brent Dickson's Contributions to Indiana Constitutional Law.

** Jon Laramore is executive director of Indiana Legal Services, Inc., a statewide non-profit law firm providing civil legal aid to low-income Hoosiers. He was previously a partner at Faegre Baker Daniels, LLP; counsel to Indiana Governors Joseph Kernan and Frank O’Bannon; a deputy attorney general in Indiana and Massachusetts; and a legal aid attorney. A graduate of Harvard Law School, the Harvard Kennedy School, and Princeton University, he has taught state constitutional law at Indiana University McKinney School of Law and is a member and former president of the Indiana Board of Law Examiners. The author thanks Janice E. Kreuscher and Daniel E. Pulliam for their thoughtful comments on a draft of this Article.

1. Although contrary to the usual style of this law review, this Article capitalizes the names of certain constitutional clauses in this Article because doing so promotes clarity.

2. Comments of Justice Brent Dickson at the Indiana University Robert H. McKinney School of Law Symposium, March 29, 2016, citing Chief Justice Shepard's opinion in Price v. State, 622 N.E.2d 954 (Ind. 1993).

http://doi.org/10.18060/4806.1130 
the standard and reifying it as the method for state constitutional interpretation. ${ }^{3}$

As Justice Dickson wrote:

Our method of interpreting and applying provisions of the Indiana Constitution is well-established, requiring

a search for the common understanding of both those who framed it and those who ratified it. Furthermore, the intent of the framers of the Constitution is paramount in determining the meaning of a provision. In order to give life to their intended meaning, we examine the language of the text in the context of the history surrounding its drafting and ratification, the purpose and structure of our constitution, and case law interpreting the specific provisions. In construing the constitution, we look to the history of the times, and examine the state of things existing when the constitution or any part thereof was framed and adopted, to ascertain the old law, the mischief, and the remedy. The language of each provision of the Constitution must be treated with particular deference, as though every word had been hammered into place. ${ }^{4}$

This interpretive standard contains strong elements of originalism as well as textualism. It makes "the intent of the framers ... paramount,", and also requires examination of the "common understanding of . . those who ... ratified [the Indiana Constitution]," incorporating the basics of originalism. The standard emphasizes the words of the constitution, but its requirement that "each provision ... be treated with particular deference, as though every word had been hammered into place," re-emphasizes the drafters' intent.

It is well beyond the scope of this Article to develop a critique of originalism. But the originalist approach directs the results in many of the cases reviewed in this Article, so the standard merits attention. ${ }^{8}$ A key criticism of originalism, pressed by Judge Richard Posner, is that determining original meaning is an impossible task: "The decisive objection to the quest for original meaning, even when the quest is conducted in good faith, is that judicial historiography rarely dispels ambiguity. Judges are not competent historians. Even real historiography is frequently indeterminate, as real historians acknowledge."

3. In contrast to Justice Dickson's well-developed standard, quoted below, Chief Justice Shepard stated in Price only that "[i]nterpretation of the Indiana Constitution is controlled by the text itself, illuminated by history and by the purpose and structure of our constitution and the case law surrounding it." 622 N.E.2d at 957 (citing State Election Bd. v. Bayh, 521 N.E.2d 1313 (Ind. 1988)).

4. Meredith v. Pence, 984 N.E.2d 1213, 1218 (Ind. 2013) (quoting Embry v. O’Bannon, 798 N.E.2d 157, 160 (Ind. 2003)).

5. $I d$.

6. $I d$.

7. $I d$.

8. See, e.g., In re Zumbrun, 626 N.E.2d 452 (Ind. 1993); Price, 622 N.E.2d 954.

9. Richard A. Posner, The Incoherence of Antonin Scalia, New REPUBlic (Aug. 24, 2012), 
Professor Eric Posner expanded this analysis, explaining why originalism is not value-free: "[O]riginalism does not enable justices to decide cases neutrally. If they choose to adopt this methodology, and manage to figure out a way to make it constrain them, they are committed to enforcing mostly $18^{\text {th }}$-century values-which are, by definition, conservative." ${ }^{\prime 10}$ Eric Posner concluded that originalism cannot resolve interpretive issues because "historical sources are rarely clear" and originalism does not dictate "how broadly constitutional principles like 'due process' and 'equal protection' should be understood." Supreme Court justices have echoed these points, noting there is no objective, neutral answer to questions such as what historical sources count, how much weight to give them, and how to resolve conflicts between them. ${ }^{12}$

Originalism also has been criticized as an inappropriate method for constitutional analysis, especially for analysis of rights-giving clauses, because the drafters purposely chose broad, expansive language and thereby intentionally gave future interpreters-including the courts-leeway to give language meaning. ${ }^{13}$ Justice Stevens voiced this criticism, stating that originalism is inimical to the framers' emphasis on expansive individual rights. ${ }^{14}$ In essence, analyzing rights from the framers' standpoint means that the rights may be applied only to circumstances within the framers' worldview and frustrates an expansive approach in new circumstances. Justice Stevens wrote that originalism "is unfaithful to the expansive principle Americans laid down when they ratified the Fourteenth Amendment and to the level of generality they chose when they crafted its language." ${ }^{\prime 5} \mathrm{He}$ also criticized originalism as value-laden, saying that "it promises an objectivity it cannot deliver and masks the value judgments that pervade any analysis of what customs, defined in what manner, are sufficiently 'rooted'; [and] it countenances the most revolting injustices in the name of continuity." 16

Critics of originalism have pointed out that if originalism - in the sense of the drafters" "intended outcome"- had been the sole measuring stick, neither Brown

https://newrepublic.com/article/106441/scalia-garner-reading-the-law-textual-originalism [https://perma.cc/FE2G-HDRA]. This point is echoed in the dissent in McDonald v. City of Chicago, 561 U.S. 742, 906-07 (2010) (Stevens, J., dissenting).

10. Eric Posner, The Tragedy of Antonin Scalia, SLATE (Feb. 15, 2016, 1:10 PM), $\mathrm{http} / / /$ www.slate.com/articles/news_and_politics/jurisprudence/2016/02/the_tragedy_of_antonin _scalia.html [https://perma.cc/YU56-XDZ2].

11. Id.

12. McDonald, 561 U.S. at 906 (Stevens, J., dissenting).

13. See Steven G. Calabresi \& Livia Fine, Symposium: Original Ideas on Originalism: Two Cheers for Professor Balkin's Originalism, 103 Nw. U. L. REv. 663, 672 (2009).

14. McDonald, 561 U.S. at 875-76 (Stevens, J., dissenting).

15. Id. at 876 .

16. Id. 
v. Board of Education ${ }^{17}$ nor Loving v. Virginia ${ }^{18}$ would have been decided as they were. ${ }^{19}$ The drafters of the Fourteenth Amendment did not intend to outlaw school segregation (as the Indiana Supreme Court held in $1874^{20}$ ), nor did they believe that it precluded the states from outlawing interracial marriage. ${ }^{21}$ As Justice Stevens has written,

Not only can historical views be less than completely clear or informative, but they can also be wrong. Some notions that many Americans deeply believed to be true, at one time, turned out not to be true. Some practices that many Americans believed to be consistent with the Constitution's guarantees of liberty and equality, at one time, turned out to be inconsistent with them. The fact that we have a written Constitution does not consign this Nation to a static legal existence. ${ }^{22}$

Justice Dickson applied the interpretative standard faithfully, as shown in the decisions discussed in the balance of this Article. This Article organizes Justice Dickson's Indiana constitutional jurisprudence into four groups: (1) cases broadly addressing fairness ${ }^{23}$; (2) cases broadly addressing access to the legal system ${ }^{24}$; (3) cases looking at the enforceability of constitutional guarantees ${ }^{25}$; and (4) cases addressing the rights of those in need of assistance because of disability or lack of income. ${ }^{26}$ This Article does not address his decisions on religion, tort law, or criminal law because other authors in this issue of the Indiana Law Review address those topics.

17. 347 U.S. 483, 495 (1954) (holding state laws establishing separate public schools for black and white students unconstitutional).

18. 388 U.S. 1, 12 (1967) (invalidating state laws prohibiting interracial marriage).

19. See Calabresi \& Fine, supra note 13, at 669-70; but see id. at 686.

20. Cory v. Carter, 48 Ind. 327 (1874), applied a kind of originalist interpretive standard (even using the formulation "the old law, the mischief, and the remedy," $i d$. at 334, as is used now) to uphold the constitutionality of the Indiana statute permitting racial segregation in common schools. The court first concluded that the framers of the Fourteenth Amendment did not intend it to reach schools at all. Id. at 352-53 (relying on The Slaughterhouse Cases, 83 U.S. 36 (1873), and State ex rel. Garnes v. McCann, 21 Ohio St. 198 (1871)). It then concluded that when the framers of article 8 , section 1 spoke of a "uniform system of common schools" that is "equally open to all," their words are "not to be taken in a literal sense," $i d$. at 334, 359, but rather the Indiana Constitution permits the General Assembly to set conditions, including race, on school attendance. Id. at 363-64.

21. Id. at 353 (quoting State v. Gibson, 36 Ind. 389 (1871)).

22. McDonald v. City of Chicago, 561 U.S. 742, 910 (2010) (Stevens, J., dissenting); see also $i d$. at 916 (Breyer, J., dissenting) ("[T] he Court should not look to history alone but to other factors as well .... It should, for example, consider the basic values that underlie a constitutional provision and their contemporary significance.").

23. See infra Part II.

24. See infra Part III.

25. See infra Part IV.

26. See infra Part V. 


\section{DECISIONS ABOUT FAIRNESS}

\section{A. Article 1, Section 23}

Justice Dickson is the primary developer of the analysis for applying the Equal Privileges and Immunities Clause in article 1, section 23 of the Indiana Constitution. $^{27}$ Before Justice Dickson's opinion in Collins v. Day, ${ }^{28}$ jurisprudence under this section had been inconsistent. One line of cases held that the Equal Privileges and Immunities Clause was substantially the same as the Equal Protection Clause of the Fourteenth Amendment to the U.S. Constitution, and that the analysis should be the same. ${ }^{29}$ Some other cases, including cases from around the time the 1851 Indiana Constitution was ratified, prescribed a separate analysis. $^{30}$

After reviewing those cases, Justice Dickson concluded in Collins that the Indiana Constitution's provision was different from equal protection and required a different analysis, basing his conclusion on the linguistic differences between the state and federal provisions and the line of Indiana cases applying a different analysis. $^{31}$

Attempting to determine "the common understanding of both those who framed ... [the 1851 Constitution] and those who ratified it," the opinion next examined the history surrounding the adoption of the provision and concluded that section 23 was intended "to prohibit the state legislature from affirmatively granting any exclusive privilege or immunity involving the state's participation in commercial enterprise." ${ }^{32}$ In particular, the drafters were concerned with the monopolistic contracts and loans previously given to companies that built public works, such as canals, a practice that led to the financial ruin that precipitated the 1850 Constitutional Convention. ${ }^{33}$

The court then looked at how this principle had been applied in cases over the years. Justice Dickson analyzed more than two dozen cases that applied the Equal Privileges and Immunities Clause between 1886 and 1974, discerning from these cases a standard, not previously articulated, that goes beyond the drafters' specific intent. ${ }^{34}$ As he put it,

where the legislature singles out one person or class of persons to receive a privilege or immunity not equally provided to others, such

27. IND. CONST. art. $1, \S 23$ ("The General Assembly shall not grant to any citizen, or class of citizens, privileges or immunities, which, upon the same terms, shall not equally belong to all citizens.").

28. 644 N.E.2d 72 (Ind. 1994).

29. See id. at 75 .

30. Id. at 74-75.

31. Id. at 75 .

32. Id. at 76-77.

33. Id.

34. Id. at 77-79. 
classification must be based upon distinctive, inherent characteristics which rationally distinguish the unequally treated classes, and the disparate treatment accorded by the legislation must be reasonably related to such distinguishing characteristics. ${ }^{35}$

Also, "any privileged classification must be open to any and all persons who share the inherent characteristics which distinguish and justify the classification." ${ }^{, 36}$

Collins was about Indiana's worker's compensation law, which exempted most agricultural employers from coverage. ${ }^{37}$ The court concluded that there were sufficient inherent differences between agricultural employers and other employers to justify disparate treatment. ${ }^{38}$ Those differences included

the prevalence of sole proprietorships and small employment units, including numerous family operations; the distinctive nature of farm work, its attendant risks, and the typical level of worker training and experience; the traditional informality of the agricultural employment relationship and the frequent absence of formal ancillary employee benefit programs; and the peculiar difficulties agricultural employers experience in passing along the additional cost of worker's compensation insurance coverage to the ultimate consumer. ${ }^{39}$

Justice Dickson expanded on Collins in three later cases in which he wrote for a majority, Paul Stieler Enterprises, Inc. v. City of Evansville, ${ }^{40}$ Myers v. Crouse-Hinds Division, ${ }^{41}$ and Whistle Stop Inn, Inc. v. City of Indianapolis,${ }^{42}$ and in his dissent in Indiana High School Athletic Ass'n v. Carlberg by Carlberg. ${ }^{43}$ Carlberg underscores Justice Dickson's emphasis on the requirement that different legislative treatment be based on inherent characteristics of the differently treated classes. ${ }^{44}$ The case examines the IHSAA's "transfer rule," which at that time penalized high school athletes who transferred from one school to another, ostensibly to discourage transfers motivated by athletic reasons - although in Carlberg's case, both sides agreed that the student's transfer

35. Id. at 78-79.

36. Id. at 79. Justice Dickson applied this same almost alchemical jurisprudential approach in Richardson v. State, 717 N.E.2d 32 (Ind. 1999), analyzing decades of decisions applying a constitutional provision (in Richardson, same-conduct double jeopardy) and extracting principles that had not previously been recognized.

37. 644 N.E.2d at 73 .

38. Id. at 81 .

39. Id.

40. 2 N.E.3d 1269 (Ind. 2014).

41. 53 N.E.3d 1160 (Ind. 2016).

42. 51 N.E.3d 195 (Ind. 2016).

43. 694 N.E.2d 222 (Ind. 1997).

44. See id. at 239. 
from one high school to another was not for athletic reasons. ${ }^{45}$ The majority recited the Collins standard and approved the IHSAA rule, finding a "reasonable relationship" between the rule and its purposes. ${ }^{46}$

Justice Dickson disagreed, finding no basis to differentiate between families' school choices based on athletics and families' school choices based on "nonathletic areas of education; such as, computer technology, foreign language, drama and performing arts, interscholastic debate competition, and marching band. ${ }^{, 77}$ To Justice Dickson, parents across the state routinely made decisions about their children's schooling that were calculated to improve their children's circumstances, sometimes including decisions about which schools had better athletic programs ${ }^{48}$ He could see no basis allowable under section 23 to penalize some families for their school choices related to athletics while not penalizing all other families that made school choices for non-athletic reasons-thus, the rule was "not justified by any inherent difference between the two classes of persons." 49

Paul Stieler, twenty years later, also focused on inherent differences, this time in the context of an anti-smoking ordinance enacted by Evansville, and Justice Dickson's view prevailed. ${ }^{50}$ The ordinance prohibited smoking in establishments such as taverns and clubs offering alcohol and food, but it permitted smoking in the riverboat gambling casino in Evansville. ${ }^{51}$ Certain tavern owners challenged the ordinance under the Equal Privileges and Immunities Clause, arguing that the casino exemption invalidated the entire ordinance, thereby negating the smoking ban in their establishments. ${ }^{52}$

The court ruled 3-2, in an opinion by Justice Dickson, that the disparate treatment accorded the casino was not reasonably related to inherent differences between the casino and taverns and clubs in Evansville, meaning that it violated the Collins standard and was unconstitutional. ${ }^{53}$ The ordinance itself identified protecting public health as its purpose, but the city defended the ordinance primarily by arguing that the casino produced significant revenue for the city and did so mainly by drawing customers from outside Evansville. ${ }^{54}$

The majority found the city had shown insufficient differences between the taverns and clubs, on one hand, and the casino, on the other, to treat them differently: "the enactment provides an unequal privilege that is not reasonably related to the inherent distinguishing characteristics of the two affected groups."

45. Id. at 226, 243 (noting IHSAA found no athletic motivation in the transfer).

46. Id. at 240 .

47. Id. at 246 (Dickson, J., dissenting).

48. Id. at 243 .

49. Id at 246.

50. Paul Stieler Enters., Inc. v. City of Evansville, 2 N.E.3d 1269 (Ind. 2014).

51. Id. at 1272 .

52. Id.

53. Id. at 1279 .

54. Id. at $1274-75$

55. Id. at 1278 . 
Paul Stieler puts essential meat on the bones of Collins by providing analysis of Collins' statement that a "classification must be based upon distinctive, inherent characteristics" ${ }^{, 56}$ that differentiate one classification from another. ${ }^{57}$ The city's attempt to justify different treatment of the casino based on its economic value to the city was insufficient, as Justice Dickson saw it. ${ }^{58}$ The casino exemption "is tantamount to the government 'selling' an exemption from the Smoking Ban for the bonus of anticipated financial benefits while burdening other citizens and snubbing our framers' intent in drafting Article 1, Section 23." 59 In other words, while the Equal Privileges and Immunities Clause was drafted to preclude providing special benefits to a single business, Evansville did precisely that by giving the casino special treatment in return for expected economic benefits for the city. ${ }^{60}$

Whistle Stop Inn analyzed a similar Indianapolis anti-smoking ordinance, banning smoking in taverns but permitting smoking in the Indianapolis off-track betting satellite gambling facility in the city. ${ }^{61}$ The expected outcome would be the same as in Paul Stieler, but instead the court-in a unanimous decision by Justice Dickson-upheld the ordinance. ${ }^{62}$ The different outcome arose because Indianapolis justified its disparate treatment of the satellite gambling facility differently than Evansville. ${ }^{63}$ Indianapolis pointed not to the revenue it received, but instead Indianapolis explained in detail that-unlike taverns-the satellite gambling facility was subject to extensive state regulation, including a requirement that the facility provide detailed plans for expelling tobacco smoke, and that those plans were evaluated and approved by the state. ${ }^{64}$ The court found that a satellite gambling facility could not exist without complying with the state regulation requiring detailed plans for smoke removal, "which thus makes [the provision] an inherent characteristic of such a facility." licensing requirement was the basis for the smoking ban exemption, Indianapolis based the exemption on an inherent difference. ${ }^{66}$

The court also ruled that the different treatment was reasonably related to the inherent difference, another Collins requirement. ${ }^{67}$ To obtain the state license, the satellite gambling facility had to obtain state approval of its smoke removal and other climate control system, allowing the state regulatory body to consider the

56. Collins v. Day, 644 N.E.2d 72, 79 (Ind. 1994) (emphasis added).

57. Paul Stieler Enters., 2 N.E.3d at 1276-78.

58. Id. at 1276 .

59. Id.

60. Id. at 1276-77.

61. Whistle Stop Inn, Inc. v. City of Indianapolis, 51 N.E.3d 195, 197-98 (Ind. 2016).

62. Id. at 197.

63. Id. at 200-01.

64. Id. at 198, 201.

65. Id. at 201.

66. Id.

67. Id. at 204. 
effect of smoking in making its licensing decision. ${ }^{68}$ Indianapolis based its exemption on the state licensing requirement, which could include consideration of the effect of smoking, "making it reasonably related to the Ordinance's exemption for satellite gambling facilities." ${ }^{, 69}$ In short, Indianapolis's justification of its no-smoking exemption met the Collins standard, while Evansville's did not.

\section{B. Article 10, Section 1}

Likely the most consequential of Justice Dickson's state constitutional decisions are the Town of St. John cases, which applied the language in article 10, section 1 requiring that "the General Assembly shall provide, by law, for a uniform and equal rate of property assessment and taxation and shall prescribe regulations to secure a just valuation for taxation of all property, both real and personal." ${ }^{, 70}$ The Town of St. John, in Lake County, sued the State Board of Tax Commissioners on behalf of some of its citizens, claiming that the state-mandated system local officials used to assess property for taxation purposes failed to satisfy the constitutional commands that it be "uniform and equal" and provide "just valuation." ${ }^{, 71}$ The town argued that the system was skewed in favor of some classes of taxpayers and against others. ${ }^{72}$ The case was handled at the trial level by the Indiana Tax Court, and the Indiana Supreme Court ultimately heard three separate appeals, two of which are relevant to the discussion of Justice Dickson's state constitutional jurisprudence. ${ }^{73}$

In the 1996 appeal, the State Board of Tax Commissioners argued that plaintiffs raised no justiciable issue because article 10 , section 1 was a guide for the legislature that lacked any standards capable of judicial application. ${ }^{74}$ The plaintiffs, on the other hand, argued that the Indiana Constitution commanded that only one approach to valuation - pure fair market valuation-would satisfy the standards in article 10 , section $1 .^{75}$

Neither side prevailed, and the court remanded the case for further proceedings in the Tax Court. ${ }^{76}$ Justice Dickson's opinion held that the standard in article 10 was susceptible to application by courts: "while courts must not

68. Id. at 201.

69. Id.

70. IND. CONST. art. $10, \S 1$.

71. Boehm v. Town of St. John, 675 N.E.2d 318, 320 (Ind. 1996). The author of this Article was counsel for the State Board of Tax Commissioners in both Town of St. John cases discussed in this Article.

72. Id.

73. The cases addressing article 1, section 10 are Boehm, 675 N.E.2d 318 and State Board of Tax Commissioners v. Town of St. John, 702 N.E.2d 1034 (Ind. 1998). The other Indiana Supreme Court case, State Board of Tax Commissioners v. Town of St. John, 751 N.E.2d 657 (Ind. 2001), addressed attorneys' fees.

74. Boehm, 675 N.E.2d at 320-21.

75. Id. at 319 .

76. Id. at 328 . 
interfere with the General Assembly's proper exercise of its constitutional prerogative to determine public policy ... the judiciary is obligated to enforce our state constitution's provisions regarding legislative action," including ruling statutes unconstitutional when necessary. ${ }^{77}$ Justice Dickson went on to review at length discussions at the Constitutional Convention about the purpose and wording of article 10 , section $1 .^{78} \mathrm{He}$ concluded that "the purpose and intent of Article 10, Section 1, was to specifically require uniform and equal assessment and taxation, and just valuation." ", He noted that the language was "aspirational" because perfect fairness could never be achieved ${ }^{80}$ Nevertheless, he wrote, the constitutional language and circumstances surrounding the adoption of article 10 "clearly demonstrate that the framers did not intend to give the legislature unrestrained discretion as to the laws of assessment and taxation." ${ }^{81}$ Rather, the courts had authority to enforce the constitutional standards. ${ }^{82}$

The court also rejected the argument that only pure fair market value assessments would satisfy the constitutional standard. ${ }^{83}$ The court stated that the purpose of article 10 was "that each taxpayer's property wealth bear its proportion of the overall property tax burden," 84 but nothing in the constitutional language suggested that there was only one assessment method that would satisfy the constitutional command, as illustrated by a number of prior cases applying the constitutional language ${ }^{85}$ The court remanded the case to the Tax Court to apply the standard enunciated in its opinion. ${ }^{86}$

The Tax Court did so, ruling in 1997 that Indiana's assessment rules violated article 10 and requiring the State Board of Tax Commissioners to consider all competent evidence when it adjudicated assessment appeals. ${ }^{87}$ The case then returned to the Indiana Supreme Court for the 1998 decision, where the Indiana Supreme Court affirmed the Tax Court's judgment in part and reversed it in part. ${ }^{88}$

In an approach echoed in other Dickson opinions, the court held that article 10 , section 1, created no "personal right of absolute uniformity and equality in assessment rate." ${ }^{89}$ Rather, that section commands the legislature to create a

77. Id. at 322 .

78. Id. at $322-23$.

79. Id. at 323 .

80. Id.

81. Id. at 324 .

82. Id.

83. Id.

84. Id.

85. Id. at 324-25. Chief Justice Shepard dissented from this portion of the opinion. See id. at 328 .

86. Id. at 328 .

87. Town of St. John v. State Bd. of Tax Comm'rs, 691 N.E.2d 1387, 1388, 1390 (Ind. T.C. 1998), aff'd in part, rev'd in part, 702 N.E.2d 1034 (Ind. 1998).

88. State Bd. of Tax Comm'rs v. Town of St. John, 702 N.E.2d 1034, 1035 (Ind. 1998).

89. Id. at 1040. Justice Dickson similarly rejected recognition of individual rights in Bonner 
system that achieves the overall effect of uniformity and equality. ${ }^{90}$ Section 1 does, however, mandate "that the assessment system must be based on objectively verifiable data to enable a review of the assessment system to ensure uniformity and equality, and to ensure that individual taxpayers have a means to assert a personal 'right of uniformity and equality' as to individual assessments." Indiana Supreme Court therefore affirmed the Tax Court's command that Indiana's assessment system must be based on objectively verifiable data "to enable review of the system to assure that it generally provides uniformity and equality based on property wealth." 92

Contrary to the Tax Court's decision, however, Justice Dickson's opinion gave the state leeway to prescribe different assessment methods for different types of property so long as the classifications of property types are "based upon differences naturally inhering in the property." ${ }^{93}$ The Supreme Court's opinion expressly permits valuation based on the actual use of property rather than its "highest and best" use. ${ }^{94}$ This approach allows, for example, land used for farming to be taxed as farm land rather than at the (often higher) value the land would command if it were sold for residential development. Applying these standards, the court invalidated Indiana's existing valuation schedules because, as the Tax Court ruled, the schedules were not based on objective evidence of property wealth. ${ }^{95}$ It additionally rejected the Tax Court's conclusion that property owners had a constitutional right to require assessing authorities to consider all evidence of property wealth; rather, because no individual had a constitutional right to a perfect assessment, state law could limit what types of evidence of property wealth had to be considered in the assessing process. ${ }^{96}$

The impact of these decisions is difficult to understate. After the decision, the General Assembly received information showing that if the decision were implemented without any other change in the law, some taxpayers-particularly homeowners, and especially those with older homes-would experience significantly increased tax bills, sometimes increases of multiples of three, four, or more. ${ }^{97}$ As a result, the General Assembly restructured Indiana's entire tax system, increasing the sales tax from $5 \%$ to $6 \%$, more than tripling the cigarette tax, and using that new revenue to replace some of the revenue raised from

v. Daniels, 907 N.E.2d 516 (Ind. 2009), and Ratliff v. Cohn, 693 N.E.2d 530 (Ind. 1998).

90. Town of St. John, 702 N.E.2d at 1039.

91. Id. (emphasis in original).

92. Id. at 1041 .

93. Id. at 1041-42 (quoting State Bd. of Tax Comm'rs v. Lyon \& Greenleaf, 172 Ind. App. 272, 277 (1977)).

94. Id. at 1042 .

95. Id. at 1043.

96. Id. Justice Sullivan dissented. He concluded the state's valuation schedules did not violate the constitution. See id. at 1044 (Sullivan, J., dissenting).

97. Larry DeBoer, Property Tax Reassessment and Tax Restructuring in Indiana, PURDUE UNIVERSITY COOPERATIVE EXTENSION SvC. (May 2003), www.agecon.purdue.edu/crd/localgov/ [https://perma.cc/G8C4-KYJQ]. 
property taxes. ${ }^{98}$ By reducing the amount of revenue to be raised from property taxes, the state could reduce property tax rates and lessen the impact on homeowners of the new assessing rules mandated by Town of St. John.$^{99}$ Much of this change took the form of using state general revenue to replace property tax revenue to fund public schools. As part of the same package, the General Assembly increased the homestead credit that homeowners could use to reduce their property tax bills. ${ }^{100}$

While these reforms had an effect, homeowners continued to complain about higher taxes under the valuation system mandated by Town of St. John ${ }^{101}$ Owners of older homes, rental housing, and farmland experienced tax hikes. ${ }^{102}$ The legislature increased the sales tax again in 2008, using the revenue in part to provide additional property tax credits for homeowners. ${ }^{103}$ As part of the same legislation, the General Assembly installed for the first time a referendum system requiring voter approval of certain local government capital projects. ${ }^{104}$

Additional pressure for taxpayer protection later in the 2000's led the General Assembly to create tax caps, limiting the property tax payment to a specified percentage of assessed valuation, initially $1.5 \%$ for homesteads, $2.5 \%$ for other residential property and farm land, and $3.5 \%$ for business property. ${ }^{105}$ The caps later were decreased to $1 \%$ for homesteads, $2 \%$ for other residential and farm land, and $3 \%$ for business property, and these caps were enacted as a constitutional amendment in $2010 .{ }^{106}$ The tax caps have led to massive losses of revenue to local governmental units including counties, cities, towns, schools, and libraries, nearly $\$ 500$ million in 2010 and almost $\$ 800$ million by $2014 .{ }^{107}$ These revenue losses have placed significant fiscal pressures on local governments, and it is possible that this legacy of Town of St. John will generate further legislative action and perhaps additional constitutional amendments to create additional capacity for local government revenue raising.

\section{Id.}

99. Id.

100. Id.

101. Larry DeBoer, What Do We Know About Indiana's Property Tax Caps?, InD. FISCAL POLICY INST. 4 (Dec. 2015), http://www.indianafiscal.org/resources/IFPI\%20Property\%20Tax\% 20Report\%20FINAL.pdf [https://perma.cc/6TL2-JL49].

102. Id.

103. Larry DeBoer, Indiana's Property Tax Reforms, 2008-2010 and Beyond, PuRduE UNIVERSITY COOPERATIVE EXTENSION SVC. 1 (July 8, 2010), https://ag.purdue.edu/arp/documents/ farm $\% 20$ policy $\% 20$ study $\% 20$ group/indiana's\%20property\%20tax $\% 20$ reforms, $\% 202008$ 2010\%20and\%20beyond,\%20deboer,\%20fpsg\%207-2010.pdf [https://perma.cc/8J92-9JEZ].

104. Id.

105. DeBoer, supra note 103, at 5-6. "Homesteads" here refers to owner-occupied dwellings.

106. Id. at 5 .

107. $I d$. 


\section{Decisions About Access to And Scope of Judicial Authority}

\section{A. Access to Courts}

Justice Dickson led the court in re-invigorating the public standing doctrine, which allows a plaintiff to sue to enforce a public duty even when the plaintiff lacks a special stake in the outcome of a case that differs from all other members of the general public. ${ }^{108}$ One of the first times he gave voice to this view was in his dissent in Pence v. State, in which a group of taxpayers sued to stop what they viewed as an unconstitutional legislative pay increase. ${ }^{109}$ In a terse opinion, the Indiana Supreme Court voted 4-1 to reject the challenge on standing grounds, holding that the plaintiffs had no standing either as citizens or as taxpayers because they could show no direct injury different than that suffered by any other citizen. ${ }^{110}$

Justice Dickson dissented, opining that the taxpayer-plaintiffs had standing both statutorily and under the public standing doctrine, which in his view gave plaintiffs "a right to challenge allegedly unconstitutional and illegal conduct of state officials ... [w] here public rather than private rights are at issue." ${ }^{111} \mathrm{He}$ also relied on the Open Courts Clause of the Indiana Constitution, which states: "All courts shall be open; and every person, for injury done to him in his person, property, or reputation, shall have remedy by due course of law."112 This language, Justice Dickson wrote, undergirds the policy of allowing plaintiffs to challenge allegedly illegal or unconstitutional government action. ${ }^{113}$

Justice Dickson won a majority for this view of standing in the Cittadine case, a landmark of standing law rooted in a local dispute over whether the state had failed to enforce a statute requiring maintenance of a clear view at a railroad grade crossing. ${ }^{114}$ Justice Dickson opened the opinion by acknowledging that to have standing in most situations, a plaintiff must show direct injury or immediate danger of direct injury from the complained-of conduct. ${ }^{115}$

His opinion then reviewed cases decided by the Indiana courts beginning in 1852 that created the public standing doctrine, which eliminates the requirement that a plaintiff show direct injury or immediate danger of direct injury when the plaintiff is seeking enforcement of a public duty or challenging certain government actions. ${ }^{116} \mathrm{He}$ restated the principle underlying these decisions:

The public standing doctrine, which applies in cases where public rather than private rights are at issue and in cases which involve the

108. State ex rel. Cittadine v. Ind. Dep't of Transp., 790 N.E.2d 978, 979-80 (Ind. 2003).

109. 652 N.E.2d 486 (Ind. 1995).

110. Id. at 487-88.

111. Id. at 489 (Dickson, J., dissenting).

112. Id.; IND. CONST. art. $1, \S 12$.

113. Pence, 652 N.E.2d at 489.

114. State ex rel. Cittadine v. Ind. Dep’t of Transp., 790 N.E.2d 978, 979 (Ind. 2003).

115. Id.

116. Id. at 980 (citing Hamilton v. State ex rel. Bates, 3 Ind. 452 (1852)). 
enforcement of a public rather than a private right, continues to be a viable exception to the general standing requirement. The public standing doctrine permits the assertion of all proper legal challenges, including claims that government action is unconstitutional. ${ }^{117}$

In such circumstances, a plaintiff need not establish unique injury because the requirement that a plaintiff have an injury different from that experienced by the general public is abrogated. ${ }^{118}$ The court clarified that the public standing doctrine does not diminish the requirement to exhaust administrative remedies or the application of statutory limitations such as the Public Lawsuit Act. ${ }^{119}$

But Justice Dickson's jurisprudence does not favor an entirely open door for litigation over public disputes; to the contrary, he has invoked other limits on judicial authority to preclude presentation of certain claims. ${ }^{120}$ In Berry $v$. Crawford, he wrote the majority opinion holding that the judiciary could not adjudicate a dispute between members of the minority and majority caucuses of the House of Representatives arising from a minority walkout. ${ }^{121}$ The minority sued when the majority fined the minority as discipline for the walkout and withheld the fines from their pay. ${ }^{122}$

No judicial remedy was available for the minority, the court held, because the separation of powers doctrine precluded relief. ${ }^{123}$ The Indiana Constitution explicitly empowered the legislative branch to enact the rules that were the basis for the fines imposed on absent legislators, to compel the attendance of absent members, and to punish members for disorderly behavior. ${ }^{124}$ Justice Dickson wrote:

[T] he constitutional grant of jurisdiction to the legislature over its internal proceedings and the discipline of its members is exclusive. Sections 10,11, and 14 of Article 4 represent an express constitutional commitment to the legislature. Absent any further express constitutional limitation or qualification on this grant of authority, the plaintiffs' claims are nonjusticiable. ${ }^{125}$

This was true, the majority wrote, despite the fact that the legislature itself had passed statutes, like the Wage Payment Statutes, that at least arguably

117. Id. at 983. On the merits, the court rejected Cittadine's challenge under the statute requiring a clear view of a railroad grade crossing from a certain distance and found his claim moot because the underlying statute had been changed during the time his lawsuit was pending. Id. at 984-85.

118. Id. at 980 .

119. Id. at 983-84.

120. See generally Berry v. Crawford, 990 N.E.2d 410 (Ind. 2013).

121. Id. at 413 .

122. $I d$.

123. Id. at 415 .

124. Id. at 418 (citing IND. ConST. art. $4, \S \S 10,11,14$ ).

125. Id. 
restricted employers from making deductions from pay such as the deductions in this case. ${ }^{126}$ The majority wrote that it could not even consider whether to apply this statute to the House of Representatives without "undermin[ing] the constitutional authority of the House [of Representatives] over the imposition and enforcement of legislative discipline." 127

\section{B. Limits on Individual Rights}

Justice Dickson wrote two other majority opinions that had similar effect but were based on different constitutional reasoning, Bonner v. Daniels ${ }^{128}$ and Ratliff v. Cohn. ${ }^{129}$ Unlike Berry ${ }^{130}$ these cases do not hinge on justiciability. Rather, echoing Justice Dickson's reasoning in the Town of St. John cases, they restrict the scope of the constitutional right that a citizen may enforce - the right to free public education in Bonner, ${ }^{131}$ and the right to treatment in a juvenile correctional facility in Ratliff..$^{132}$

In Bonner, a group of public school students sued state officials, claiming that various state actions and policies deprived them of free, quality, public education guaranteed by article 8 , section $1 .{ }^{133}$ The court parsed the text of this provision and held that it "speaks only of a general duty to provide for a system of common schools and does not require the attainment of any standard of resulting educational quality." 134 In other words, the Indiana Constitution "says nothing whatsoever about educational quality."135 Because the Indiana Constitution imposed no quality standard, the courts could not enforce one, and the plaintiffs had no cause of action. ${ }^{136}$

In Ratliff, a juvenile who had been convicted of a serious crime claimed a

126. Id. at 420 .

127. Id.

128. 907 N.E.2d 516 (Ind. 2009).

129. 693 N.E.2d 530 (Ind. 1998).

130. 990 N.E.2d at 422.

131. 907 N.E.2d at 518-19.

132. 693 N.E.2d at 546. The author of this Article was counsel for the state defendants in Ratliff. Id. at 532 .

133. 907 N.E.2d at 518 .

Knowledge and learning, generally diffused throughout a community, being essential to the preservation of a free government; it shall be the duty of the General Assembly to encourage, by all suitable means, moral, intellectual, scientific, and agricultural improvement; and to provide, by law, for a general and uniform system of Common Schools, wherein tuition shall be without charge, and equally open to all.

Id. at 520 (citing IND. CoNST. art. 8, §1) (emphasis in original).

134. Id. at 521 .

135. Id.

136. Id. at 522. The court also rejected arguments based on article 1, sections 12, 23. Id. Justice Boehm concurred in result, and Justice Rucker dissented. Id. at 523-24 (Boehm, J., concurring), 524-25 (Rucker, J., dissenting). 
right to be held in one of the juvenile correctional facilities created under the command in article 9, section 2, that the legislature "provide institutions for the correction and reformation of juvenile offenders." 137 Similar to Bonner, the court ruled:

[W] hile the Constitution clearly requires the General Assembly to create a House of Refuge [the original constitutional phrase, later replaced by the current language] to provide alternative reformation and incarceration opportunities for juvenile offenders, what is not clear is whether the framers intended that every juvenile convicted of an adult crime be sent to the House of Refuge. ${ }^{138}$

The court scoured the debates at the constitutional convention and found "no historical evidence of contemporaneous public expectation that the new constitution was intended to prohibit the incarceration of any and every juvenile offender in an adult prison." 139

This line of reasoning shows the power of the interpretive standard discussed in Part I above. In short, the court asked not whether any overriding constitutional purpose, social science evidence, pragmatic reasoning, experience about how individuals are best rehabilitated, or even contemporary sensibilities suggested that juvenile prisoners should be held separate from adults; it asked only whether those who wrote the Indiana Constitution in 1850 and certain statutes passed immediately afterward insisted on that separation. ${ }^{140}$ Based on this reasoning, the court ruled that while the constitution required that institutions for juvenile incarceration be created, it vested no individual right that any particular juvenile be housed in such an institution. ${ }^{141}$

Justice Dickson also authored a unanimous opinion precluding access to the courts by prisoners seeking review of internal prison disciplinary decisions in Zimmerman v. State. ${ }^{142}$ Despite the Open Courts Clause and the settled principle of Indiana law that a party is entitled to one judicial appeal of an administrative action, the court rejected Zimmerman's effort to appeal a prison administrator's decision to restrict his visitation privileges for disciplinary reasons. ${ }^{143}$ The court stated that "[n]either Indiana statutes nor common law rules establish [a prisoner's] right to judicial review of prison disciplinary action."144

137. 693 N.E.2d at 534 (quoting IND. CONST. art. 9, § 2).

138. Id. at 535-36 (emphasis in original).

139. Id. at 537.

140. Id. at 540 .

141. Id. at $540-41$.

142. 750 N.E.2d 337, 337-38 (Ind. 2001).

143. Id.; see IND. Const. art. 1, § 12 (Open Courts Clause); see also Warren v. Ind. Bell Tel. Co., 26 N.E.2d 399 (Ind. 1940) (judicial review of administrative decision).

144. Id. at 338 (quoting Hasty v. Broglin, 531 N.E.2d 200, 201 (Ind. 1989)). 


\section{Justice Dickson's Role in Other Significant Decisions}

\section{A. Special Laws Clauses}

Justice Dickson made a significant contribution to enforcement of the Special Law Clauses, article 4, sections 22 and 23, in State v. Hoovler. ${ }^{145}$ Like Town of St. John, Bonner, and Ratliff, Hoovler involved portions of the constitution outside article 1, the so-called Bill of Rights. ${ }^{146}$ But the justices nevertheless found the Special Law Clauses enforceable by private parties-even though they are structured as commands to the General Assembly like the provisions the court held to convey no enforceable, individual rights in cases like Town of St. John, Ratliff, and Bonner. ${ }^{147}$

The modern doctrine of the Special Laws Clauses developed over several cases, starting with Indiana Gaming Commission v. Moseley, which upheld the constitutionality of the statute allowing riverboat gaming but limited riverboat gaming to certain locations, namely communities along Lake Michigan, the Ohio River, and Patoka Lake. ${ }^{148}$ The court analyzed the statute first under section 22, which prohibits special laws in seventeen enumerated categories, finding that the law allowing riverboat gaming fell into none of those categories and was therefore not prohibited by section $22 .{ }^{149}$ It then analyzed the statute under section 23 , which prohibits special laws "where a general law can be made applicable" and ruled that the statute did not violate section 23 because a special law was necessary to limit gaming to locales that would support gaming on boats. ${ }^{150}$ Moseley should have ended forever the canard that the Indiana Constitution prohibits special laws: it prohibits only some special laws.

Justice Dickson's Hoovler decision followed two years later and further developed the law under both sections 22 and $23 .{ }^{151}$ In Hoovler, taxpayers sued over a special law that allowed Tippecanoe County to enact a tax to fund cleanup of a landfill. ${ }^{152}$ The court first determined that the statute did not violate section $22 .{ }^{153}$ Plaintiffs argued that it was a special law "providing for the assessment and collection of taxes." ${ }^{154}$ Applying the familiar interpretive standard, Hoovler

145. See generally 668 N.E.2d 1229 (Ind. 1996). The author of this Article was counsel for the state in Hoovler. Id. at 1230.

146. Id. at 1231 .

147. Id. at 1233-36; see generally Bonner v. Daniels, 907 N.E.2d 516 (Ind. 2009); State Bd. of Tax Comm'rs v. Town of St. John, 702 N.E.2d 1034 (Ind. 1998); Ratliff v. Cohn, 693 N.E.2d 530 (Ind. 1998).

148. Ind. Gaming Comm'n v. Moseley, 643 N.E.2d 296, 298, 301, 305 (Ind. 1994). Chief Justice Shepard wrote Moseley. Id. at 297.

149. Id. at 298-301.

150. Id. at 300-03.

151. See generally Hoovler, 668 N.E.2d at 1231.

152. Id. at 1231-32.

153. Id. at 1233 .

154. Id. at 1232 . 
instructs that every word of the Indiana Constitution is to be read with care. ${ }^{155}$ Doing so, the court concluded the statute did not offend section 22 because it was not a special law for the assessment of taxes (that is, how to value property) because it did not prescribe special assessing methods for any location; nor was it a special law for the collection of taxes because it would be collected just like taxes in all other counties. ${ }^{156}$ The statute permitted an increase in only the tax rate, and that action is not on the list of prohibited special laws in section $22 .{ }^{157}$

Following Moseley, Hoovler also concluded that the special law did not violate section 23 because special conditions in Tippecanoe County permitted the General Assembly to treat that county differently. ${ }^{158}$ The trial court had made a finding that Tippecanoe County was the only county in Indiana that faced cleanup of a landfill that-under the applicable federal Superfund environmental law-would be paid for by a state university, a county, and a municipality. ${ }^{159}$ The court concluded that it was appropriate to allow the special tax rate, which was necessary to fund a settlement that had been arrived at to clean up the landfill, rather than requiring lengthy, expensive litigation under the Superfund law. ${ }^{160}$

Another important element of Hoovler is its footnote $3 .{ }^{161}$ The opinion notes that the legislature identified Tippecanoe County not by name, but rather by its population: a county "having a population of more than one hundred twenty-nine thousand $(129,000)$ but less than one hundred thirty-thousand six hundred $(130,600)$," with Tippecanoe County being the only county with a population falling within these parameters. ${ }^{162}$ The court stated that it would determine whether a law is special (that is, applies only in one or a very small number of locations) not by the manner in which the legislature designates the location, but by the actual effect of the legislation. ${ }^{163}$ Despite some earlier cases that could be read to the contrary, designating the locations by population limits

does not convert an otherwise special law into a general and uniform law. When the legislature seeks to address a special or local problem that cannot be resolved through the use of a general law, the General Assembly may enact a special law plainly designating its intended beneficiary and without employing the subterfuge of population limits, so long as it does not violate the strictures of Article IV, $\S 22 .{ }^{164}$

155. Id. at 1233 .

156. $I d$.

157. Id. at $1233-34$.

158. Id. at 1235 .

159. Id.

160. Id. at $1235-36$.

161. Id. at 1233 n.3.

162. Id. at 1231.

163. Id. at 1234 .

164. Id. at 1233 n.3 (citations omitted) (citing Ind. Gaming Comm'n v. Moseley, 643 N.E.2d 296, 298, 301 (Ind. 1994)). At some point, the General Assembly may have attempted to circumvent the Special Laws Clauses by using population demarcations based on the argument that 


\section{B. Article 1, Section 9}

The modern Indiana Supreme Court first began plowing new ground under the Indiana Constitution in Price v. State, ${ }^{165}$ addressing the right to free expression in article 1, section 9. ${ }^{166}$ In short, the court in Price set aside a conviction for disorderly conduct arising from Price's shouted and sometimes profane comments about police conduct while she was being arrested. ${ }^{167}$ The majority ruled that Price's conduct was constitutionally protected political speech about police conduct, a public issue, and that political speech was a "core value" under article 1, section 9 of the Indiana Constitution that was "materially burdened" by Price's conviction. ${ }^{168}$ The majority vacated her conviction after determining, on the facts of this particular case, that her constitutional right to free expression outweighed the privacy interests of others subjected to her noise. ${ }^{169}$

Justice Dickson dissented. ${ }^{170}$ His analysis relied in part on the language of section 9, which states, "[n] law shall be passed, restraining the free interchange of thought and opinion, or restricting the right to speak, write, or print, freely, on any subject whatever" but concludes, "but for the abuse of that right, every person shall be responsible." "Justice Dickson argued that Price's conduct fell within the plain meaning of "abuse of that right" and therefore was punishable without contravening article 1 , section $9 .{ }^{172} \mathrm{He}$ also expressed skepticism about the majority's "core constitutional value" analysis, which Price introduced, even though Justice Dickson himself later used that same analysis. ${ }^{173}$ Justice Dickson's

other jurisdictions could move into and out of those classifications as their populations changed. But the General Assembly's own actions undermined this approach. The legislature mandated the use of decennial census populations to determine which localities fit into any given population range and, after each new census, the General Assembly enacted a bill that changed all the population ranges in all affected statutes so that only the same localities as had previously been covered by those special laws remained in those categories as identified by the new census numbers despite population changes. See generally IND. CoDE § 2-1-9 (2016).

165. 622 N.E.2d 954 (Ind. 1993).

166. Chief Justice Shepard announced the court's interest in the Indiana Constitution in his article, Second Wind for the Indiana Bill of Rights, 22 IND. L. REV. 575 (1989); see also Patrick Baude, Has the Indiana Constitution Found its Epic?, 69 IND. L.J. 849 (1994) (citing Price as the potential beginning of a new era of individual rights under the Indiana Constitution).

167. 622 N.E. $2 d$ at $956-57$.

168. Id. at 958-63.

169. Id. at 964-65.

170. Id. at 967 (Dickson, J., dissenting).

171. Id. at 968 (emphasis in original).

172. Id. This portion of Justice Dickson's dissent also includes his advocacy of defining the words of the constitution using popular dictionaries, which he asserted would show how the voters who ratified the Indiana Constitution understood it, rather than legal dictionaries. Id.

173. Id. at 969. For Justice Dickson's later use, see, for example, City Chapel Evangelical 
analysis was in some ways prescient, as whatever promise Price may have had has not been delivered on, either in the free expression area or generally in development of individual rights under the Indiana Constitution. Later cases have significantly restricted Price, and no more than a handful of later convictions have been reversed based on Price's analysis. ${ }^{174}$ Moreover, the "core constitutional value" concept has not been the subject of significant further development, and the Indiana Constitution has not been a source of significant additional individual rights in the ensuing years. ${ }^{175}$

\section{Article 1, Section 21}

Bayh v. Sonnenburg was a high-profile 1991 case applying the provisions of article 1, section 21 , which states, "[n]o person's particular services shall be demanded, without just compensation" $" 176$ in the context of work that was required to be performed by those residing in Indiana's mental hospitals. ${ }^{177}$ A trial court had concluded that residents of mental hospitals were routinely required to perform work tasks at the hospitals, such as groundskeeping and food preparation, and they were entitled to compensation for those services. ${ }^{178}$ The trial resulted in a multimillion dollar verdict against the state. ${ }^{179}$

The majority reversed the judgment under article 1 , section 21 , holding that the services demanded from residents were not "particular services" as meant by the Indiana Constitution and that, even if particular services had been demanded, the room and board provided to the residents should be counted in determining "just compensation.",

Justice Dickson dissented ${ }^{181} \mathrm{He}$ concluded, different from the majority, that the services the state demanded from residents were "particular services." ${ }^{182}$ His

Free Inc. v. City of South Bend, 744 N.E.2d 443 (Ind. 2001).

174. See, e.g., Dallaly v. State, 916 N.E.2d 945, 954 (Ind. Ct. App. 2009) (speech interfering with police officer's duties is not protected); J.D. v. State, 859 N.E.2d 341, 344 (Ind. 2007) (political speech that obscures a police officer's attempts to speak and function as a law enforcement officer violated section 9).

175. The Indiana Supreme Court has interpreted the Indiana Constitution to provide additional protections, beyond those conveyed by the U.S. Constitution, in the areas of same-conduct double jeopardy, search and seizure, and possibly some aspects of free exercise. See generally Litchfield v. State, 822 N.E.2d 973 (Ind. 2004); City Chapel Evangelical Free Inc., 744 N.E.2d 443; Richardson v. State, 717 N.E.2d 32 (Ind. 1999).

176. IND. CONST. art. $1, \S 21$.

177. 573 N.E.2d 398, 400-02, 411 (Ind. 1991).

178. Id. at 400 .

179. Id. at 400-01. The case also contained other claims, including unjust enrichment and violation of the Thirteenth Amendment, which are not addressed in this Article. Id. at 408-11.

180. Id. at 414-17, 421 .

181. Id. at 421(Dickson, J., dissenting). The description in this Article is limited to Justice Dickson's dissent on the Indiana constitutional issues.

182. Id. at 426 . 
analysis concluded that the phrase "particular services" "was utilized to identify services not equally required of all citizens," and the services demanded of mental hospital residents were particular services because they were not demanded of all citizens - in contrast to jury duty, demanded of all citizens, and the pioneer practice of demanding from all citizens a number of days' work on common roadways each year. ${ }^{183} \mathrm{He}$ would have affirmed the residents' judgment against the state on this ground. ${ }^{184}$

Justice Dickson also took issue with the majority's "rationale for finding that the plaintiffs' right to just compensation is precluded by inferred extrinsic benefits," that is, that any judgment that plaintiffs received should be reduced by the value of their room and board. ${ }^{185}$ Justice Dickson acknowledged that, when calculating damages for taking property, "extrinsic benefits are considered to the extent that the pecuniary value of a person's remaining property is enhanced." 186 But he argued that the same principles do not allow benefits to be counted against the value of a person's particular services in the way the majority would have done.$^{187}$ Rather, analogizing the extrinsic benefits rule to takings of particular services "would require that the extrinsic benefits to be considered are restricted to the pecuniary benefits to the person's remaining services." 188 In other words, damages to the residents should be reduced by only the value of increased marketable skills the residents obtained through their required labor. ${ }^{189} \mathrm{He}$ also argued that whether to count any extrinsic benefits in this context was discretionary and in no way compelled by the Indiana Constitution. ${ }^{190}$

183. Id. at 424-26. The road maintenance example as well as time demanded for unpaid training for the state militia are addressed in the majority opinion. Id. at 411-13 (majority opinion).

184. Id. at 424-26 (Dickson, J., dissenting). Justice Dickson briefly addressed the same issue in his dissent in Cheatham v. Pohle. See generally 789 N.E.2d 467, 477 (Ind. 2003) (Dickson, J., dissenting). That case examined the constitutionality of a statute that required three-quarters of every punitive damage award to be paid not to the tort plaintiff, but to the Victims of Violent Crimes Compensation Fund. Id. at 470 (majority opinion). The majority found the statute constitutional. Id. at 477. One basis for Justice Dickson's dissent was his view that it unconstitutionally demanded lawyers' particular services without compensation. Id. at 478 (Dickson, J., dissenting). Rather than providing reasoning, his dissent adopts the Court of Appeals' opinion, which concluded that lawyers' services in these cases are particular services because they have been compensated historically and are not demanded of the general public; they are demanded because the state takes a portion of the judgment that includes what would otherwise be the lawyers' fee; and that they are not compensated. Id. (citing Cheatham v. Pohle, 764 N.E.2d 272, 277-81 (Ind. Ct. App. 2002)).

185. Sonnenburg, 573 N.E.2d at 426; see id. at 420-21 (majority opinion regarding extrinsic benefits).

186. Id. at 426 (Dickson, J., dissenting) (emphasis in original).

187. Id.

188. Id. (emphasis in original).

189. Id.

190. Id. 


\section{Justice Dickson's Decisions Affecting Those Less Fortunate}

In addition to Ratliff, Bonner, and Bayh, Justice Dickson wrote several other decisions affecting those who are impoverished or otherwise less fortunate.

Justice Dickson dissented in two cases applying article 1 , section 22 which states: "The privilege of the debtor to enjoy the necessary comforts of life, shall be recognized by wholesome laws, exempting a reasonable amount of property from seizure or sale, for the payment of any debt or liability . . . " ${ }^{191}$ In In re Zumbrun, the majority found unconstitutional a statute exempting from execution for payment of debts all of a debtor's interests in pension funds, retirement funds, and individual retirement accounts. ${ }^{192}$ The majority concluded that this exemption was not a reasonable balance of the interests of debtors and creditors. ${ }^{193}$

Justice Dickson's dissent pointed out that the Indiana Constitution itself does not impose any maximum limitation on exemptions but instead delegated to the General Assembly the responsibility to enact "reasonable" exemptions. ${ }^{194} \mathrm{He}$ dissented because the majority's opinion contradicted principles of judicial restraint that would have deferred to the legislative decision as to what constitutes "reasonable" exemptions. ${ }^{195}$

Justice Dickson concurred in another case involving the same constitutional provision, Citizens National Bank v. Foster ${ }^{196}$ which analyzed the amended exemption provision enacted after Zumbrun. The new law exempted all contributions to an individual retirement account that were tax-deferred at the time they were made. ${ }^{197}$ The majority, although critical of the provision, did not find it unconstitutional as applied in this case, where the individual retirement account contained only $\$ 3,600 .{ }^{198}$ Justice Dickson's concurrence repeated the approach he took in Zumbrun and found no problem with the statute. ${ }^{199}$

Justice Dickson wrote the majority opinion in one of the few cases applying the Contracts Clause of the state constitution, Clem v. Christole, Inc., in which the question was whether a restrictive covenant precluding a group home for developmentally disabled or mentally ill persons could be enforced in light of a

191. IND. CONST. art. $1, \S 22$.

192. 626 N.E.2d 452, 453 (Ind. 1993) (citing IND. CODE § 34-2-28-1(a)(6) (1991) (repealed in 1998)).

193. Id. at 455 .

194. Id. at 455-56 (Dickson, J., dissenting). As to the application of the standards for addressing constitutional questions, while the majority relied on certain statements by delegates to the Constitutional Convention, Justice Dickson pointed out that those who ratified the 1851 Constitution "were not voting to ratify individual speeches of particular delegates ... [,]" but rather for the constitution as written. $I d$. at 456 .

195. Id. at 456 .

196. 668 N.E.2d 1236, 1238 (Ind. 1996).

197. Id. at 1240 .

198. Id. at 1242 .

199. Id. at 1243 (Dickson, J., concurring). 
statute retroactively invalidating such restrictions. ${ }^{200}$ Clem summarized the Contracts Clause as follows: "Valid existing contracts cannot be impaired by future legislation 'except in a proper exercise of the police power of the state." ${ }^{201}$ The police power is invoked to "promote the order, safety, health, morals, and general welfare of society" but must be "necessary to meet an important general social problem." 202 Justice Dickson concluded that the statute prohibiting restrictive covenants could withstand constitutional scrutiny only if it fit within what he called the "necessary police power," that is, "necessary for the general public and reasonable under the circumstances." ${ }^{203} \mathrm{He}$ concluded that the statute did not pass that test and therefore was invalid because the statute "[was] not reasonably necessary for the protection of the health, safety, and welfare of the general public. It d[id] not address a broad problem general to society."204

Finally, Justice Dickson addressed the role of lawyers in serving the poor in his dissent in Sholes v. Sholes. ${ }^{205}$ Sholes, who was incarcerated in a state correctional facility, sought counsel in a civil case under a statute requiring that counsel be appointed for an indigent party who does not have "sufficient means to prosecute or defend" a civil case. ${ }^{206}$ The majority explained the criteria for determining whether Sholes had satisfied the statute and ruled that if he was deemed indigent and unable to represent himself, counsel had to be appointed for him. ${ }^{207}$ The majority also ruled that counsel had to be compensated because not compensating counsel would violate article 1, section 21 , which bans taking "particular services" without compensation. ${ }^{208}$ The crux of the court's opinion was its conclusion that when there is no source of funds to pay counsel-as was true in this case- a trial court should decide whether to appoint counsel based on whether the party has a colorable claim, whether the party is able to selfrepresent, whether counsel is available from a pro bono source or through a contingent fee, and whether making an order requiring payment of public funds for appointed counsel would severely affect other governmental fiscal interests. ${ }^{209}$

Justice Dickson's dissent was limited to whether counsel appointed under the statute had to be paid, and he opined that appointed counsel was required to serve without compensation. ${ }^{210}$ Looking at constitutional history, he concluded that

200. 582 N.E.2d 780, 781 (Ind. 1991) (citing IND. CoDE § 16-13-21-14 (1991) (repealed in 1992)).

201. Id. at 782 (quoting Bruck v. State ex rel. Money, 91 N.E.2d 349, 352 (Ind. 1950)).

202. Id. at 782-84 (quoting Bruck, 91 N.E.2d at 352; Allied Structural Steel Co. v. Spanaus, 438 U.S. 234,249 (1978)).

203. Id. at 784 .

204. Id. Justice Krahulik wrote a dissenting opinion, joined by Justice DeBruler. Id. at 785-88 (Krahulik, J., dissenting).

205. See 760 N.E.2d 156, 167 (Ind. 2001) (Dickson, J., concurring and dissenting).

206. Id. at 157-58 (citing IND. CoDE $\S \S 34-10-1-1,2$ (2001) (amended in 2002)).

207. Id. at $160-61$.

208. Id. at 163-64.

209. Id. at 164-66.

210. Id. at 167 (Dickson, J., concurring and dissenting). 
counsel were mandated to provide free services at the time the 1851 Constitution was ratified, and "nothing in the history surrounding the adoption of our Constitution ... suggests that Section 21 was intended to change the thenprevailing practice." 211 Furthermore, he opined that lawyers have a "special obligation of providing free legal service to indigent clients" that is "an inherent aspect of being a lawyer. It comes with the territory." 212

\section{CONCLUSION}

Many trace the modern development of Indiana constitutional law to Chief Justice Shepard's 1989 law review article, Second Wind for the Indiana Bill of Rights. ${ }^{213}$ If it was Chief Justice Shepard who invited Indiana lawyers to use the state constitution, it was Justice Dickson who did more than any other recent justice to give Indiana lawyers the tools to use it. His synthesis of standards in areas such as equal privileges, double jeopardy, and special laws gave advocates the ability to advance arguments under the Indiana Constitution. His practical approach, citing contemporaneous dictionaries, census data, old treatises, and statutes and case authority from around the time the constitutional provision was adopted showed lawyers how to argue successfully. Justice Dickson also took these ideas into the classroom, teaching classes on state constitutional law at both Indiana University Robert H. McKinney School of Law and Indiana University Maurer School of Law and developing a casebook that has been used-sometimes in updated forms - by many others teaching about the Indiana Constitution at McKinney, Maurer, Valparaiso University School of Law and now at Indiana Tech Law School. These activities have been vital to the development of advocacy under the Indiana Constitution.

Justice Dickson made significant contributions to the development of Indiana constitutional law during his thirty-year career. He is chiefly responsible for crafting the modern standards applying the Equal Privileges and Immunities Clause. ${ }^{214} \mathrm{He}$ advocated, first in dissent, and then writing for majorities, revival of the public standing doctrine, allowing citizens to obtain judicial review on questions of public rights and constitutionality. ${ }^{215} \mathrm{He}$ authored the key opinions requiring wholesale revamping of property tax assessment practices, leading to far-reaching and still-developing consequences. ${ }^{216} \mathrm{He}$ also helped to develop principles for applying the Special Laws Clauses, which limit legislative authority

211. Id. at 168 .

212. Id.

213. Shepard, supra note 166.

214. See Paul Stieler Enters., Inc. v. City of Evansville, 2 N.E.3d 1269 (Ind. 2014); Collins v. Day, 644 N.E.2d 72 (Ind. 1994).

215. See Berry v. Crawford, 990 N.E.2d 410 (Ind. 2013); State ex rel. Cittadine v. Ind. Dep't of Transp., 790 N.E.2d 978 (Ind. 2003); Pence v. State, 652 N.E.2d 486 (Ind. 1995).

216. See Town of St. John v. State Bd. of Tax Comm'rs, 691 N.E.2d 1387 (Ind. T.C. 1998); Boehm v. Town of St. John, 675 N.E.2d 318 (Ind. 1996). 
to make local policies. ${ }^{217}$

Yet he was deferential to the legislative branch in other context, declining (unlike in some other states) to allow judicial review of the adequacy of education financing, the rights of juveniles to be incarcerated separate from adults, and the application of certain statutes to the legislative branch itself. ${ }^{218}$

Justice Dickson also is as responsible as any justice for the interpretive standard adopted by the modern court for application to state constitutional questions, a standard that adopts significant elements of originalism and can be criticized as unnecessarily narrow and restrictive. The upcoming decades will determine which of Justice Dickson's many contributions will withstand the test of time and experience.

217. State v. Hoovler, 668 N.E.2d 1229 (Ind. 1996); Ind. Gaming Comm'n v. Moseley, 643 N.E.2d 296 (Ind. 1994).

218. See, e.g., Bonner v. Daniels, 907 N.E.2d 516 (Ind. 2009); Ratliff v. Cohn, 693 N.E.2d 530 (Ind. 1998). 